\title{
Priprava elektrolučno taljenog magnezijeva oksida iz kalciniranog magnezita za uporabu u elektrotermiji
}

\section{S. Hoda," I. Zeqiri, M. Sadiku, M. Kelmendi i B. Baruti}

Fakulteti i Gjeoshkencave dhe Teknologjisë, PIM Trepça, 40000 Mitrovicë, Kosovo

\begin{abstract}
U današnje vrijeme postoji velika potreba za materijalima koji mogu podnijeti oksidacijske uvjete na vrlo visokim temperaturama. Pogodan materijal za takvu primjenu je elektrolučno taljeni magnezijev oksid (MgO), s talištem $2825{ }^{\circ} \mathrm{C}$, koji je od velike važnosti za proizvodnju visoko vatrostalnih materijala. Kristali $\mathrm{MgO}$ dobiveni iz taline pravilnije su građe, s manje strukturnih pogrešaka u usporedbi s kristalima koji nastaju sinteriranjem na nižim temperaturama.

Cilj rada priprava je vrlo čistog elektrolučno taljenog MgO iz kalciniranog magnezita za uporabu u elektrotermiji. $U$ istraživanjima su upotrijebljeni uzorci magnezita $\left(\mathrm{MgCO}_{3}\right)$ iz ležišta Strezovce, Kosovo, za pripravu vrlo čistog MgO taljenog u peći za elektrolučno taljenje u Kosovskoj Kamenici. Nakon priprave granuliranog taljenog MgO, pri čemu su kontrolirani atmosfera, temperatura i trajanje obrade, određeni su parametri optimalne toplinske obrade i mikrotvrdoća.

Na temelju izvedenih istraživanja može se zaključiti da je, uz optimalne uvjete u svim fazama postupka, iz kalciniranog magnezita ležišta Strezovce moguća priprava taljenog MgO za primjenu u elektrotermiji, koji je kvalitetom usporediv s MgO dostupnim na svjetskom tržištu.

Ključne riječi: Elektrolučno taljeni MgO, peć, sinteriranje, elektrotermija, toplinska obrada, mikrotvrdoća
\end{abstract}

\section{Uvod}

U posljednje vrijeme u svijetu postoji velika potražnja za materijalima koji mogu podnijeti oksidacijske uvjete na vrlo visokim temperaturama. Najvažniji je materijal za ovakvu primjenu elektrolučno taljeni magnezijev oksid (MgO) s talištem pri $2825^{\circ} \mathrm{C}$, koji je od velike važnosti u proizvodnji visoko vatrostalnih materijala. Njegova kristalna struktura, modela jednostavne kubične ćelije s dvije vrste atoma (kao i NaCl), pod opterećenjem dopušta pojavu određenih plastičnih deformacija koja su vrlo poželjna u određenim primjenama. Promjenom tlaka i temperature $\mathrm{MgO}$ ne prekristalizira u druge polimorfe. Posebnu primjenu monokristalni i polikristalni MgO nalazi zahvaljujući elektroizolacijskim osobinama i relativno velikoj toplinskoj provodnosti. Slabom elektroprovodnošću MgO se svrstava u skupinu dielektrika., ${ }^{1,2}$

Budući da je prirodni MgO uvijek onečišćen, a za primjenu (elektrotermija, radiotehnika itd.) potrebni su što čistiji kristali, u posljednje vrijeme razvijaju se postupci za proizvodnju čistog MgO. Jedan od postupaka za dobivanje vrlo čistog MgO jest taljenje u elektrotalioničkoj peći, u kojoj je moguće postići temperature iznad tališta čistog MgO, a kristali nastali iz taline imaju pravilniju građu s manje strukturnih pogrešaka u usporedbi s kristalima MgO koji se dobivaju sinteriranjem pri nižim temperaturama. Elektrolučno taljeni vatrostalni materijal na bazi MgO sve je više u upo-

\footnotetext{
* Autor za dopisivanje: Dr. sc. Selver Hoda, Lagja e Universitetit nr 2, 40000 Prishtinë, Kosovo, e-pošta: selverhoda@hotmail.com
}

rabi jer se uspjelo podići temperaturu sinteriranja od 1700 do $1800{ }^{\circ} \mathrm{C}$. U usporedbi sa sinteriranim MgO, taljeni MgO odlikuje se pravilnim i velikim "idealnim" kristalima periklasa. Maksimalna veličina kristala periklasa kod sinteriranog MgO iznosi oko 150 mm, dok kod taljenog MgO kristali periklasa dostižu veličinu i do nekoliko centimetara. S veličinom kristala povećava se otpornost na taljenje i postojanost pri duljim izloženostima proizvoda temperaturama iznad $1700{ }^{\circ} \mathrm{C}$. Osim toga kristali periklasa nastali iz taline pokazuju manji stupanj strukturnih pogrešaka s dobro razvijenim plohama kalavosti, uz povećanu plastičnost i termostabilnost, i otporni su na hidrataciju. Zrnasti elektrolučno taljeni MgO može se proizvesti taljenjem kaustičnog pečenog magnezita $(\mathrm{MgO})$, sintermagnezita (MgO) ili brucita $\left(\mathrm{Mg}(\mathrm{OH})_{2}\right){ }^{3}{ }^{3}$ Sirovina za taljenje treba sadržavati što manje oksida drugih elemenata, koji negativno utječu na kvalitetu elektrolučno taljenog MgO. Ovisno o vrsti proizvoda materijal se u peći tali na temperaturama $1800-2500{ }^{\circ} \mathrm{C}$. Osnovna prednost elektrolučno taljenih materijala $u$ odnosu na klasične materijale dobivene sinteriranjem jest njihova stabilnost i homogeniji sastav. Taljenjem materijala i usporenim odnosno ubrzanim hlađenjem kristaliziranost se može povećati ili smanjiti. Taljenjem se proizvod može i očistiti od nečistoća $\left(\mathrm{Fe}_{2} \mathrm{O}_{3}\right.$ $\mathrm{SiO}_{2}, \mathrm{CaO}, \mathrm{TiO}_{2}$, alkalije), čime se produkt oplemenjuje. Taj se postupak naziva rafinacijom, a ostvaruje se gravitacijskom difuzijom primjesa prema donjim zonama, difuzijom prema bočnim područjima zbog temperaturnog gradijenta, zonskom kristalizacijom MgO kao i redukcijom određenih primjesa ugljikom iz elektroda. ${ }^{4}$ 
Međutim proces taljenja ima i nedostatke. To su nastajanje kristala različitih veličina prema temperaturnim zonama koje postoje u bloku za vrijeme kristalizacije (hlađenja), mogućnost nastajanja staklaste faze u većoj količini odnosno skupljanje nečistoća u jednom dijelu bloka (na obodu). Kemijska homogenost mora se postići odgovarajućim izborom sirovina i njezinom pripremom, jer se u peći za taljenje ne može osigurati homogeniziranje samo konvekcijskim strujanjem, dok je mehaničko miješanje taline teško ostvariti. Homogeniziranje sastava taline u peći produljenjem trajanja grijanja može izazvati suprotan učinak zbog pregrijavanja taline, koje je često praćeno isparavanjem korisne komponente. ${ }^{5}$ To je uobičajena pojava kod taljenja $\mathrm{MgO}$, a u manjem opsegu i kod taljenja alumosilikata u redukcijskoj sredini, neovisno o tome što u oksidacijskoj atmosferi $\mathrm{MgO}, \mathrm{SiO}_{2} \mathrm{i} \mathrm{Al}_{2} \mathrm{O}_{3}$ imaju znatno viša vrelišta. Zbog toga se pregrijavanje taline mora ograničiti na nekoliko minuta i svega $100-200{ }^{\circ} \mathrm{C}$ iznad tališta.

Kristalizacija i očvršćivanje taljenog materijala zbiva se u istoj peći u kojoj je materijal taljen (diskontinuirani rad pod uobičajenim nazivom blok-taljenje). Ovakav postupak primjenjuje se kod svih elektrolučno taljenih materijala koji se dobivaju u zrnastom obliku, ${ }^{6}$ kao što su elektrolučno taljeni korund za abrazive i elektrolučno taljeni MgO (vatrootporne mase, nabojne mase, elektrotermija i dr.). Elektrolučno taljeni vatrostalni materijali na bazi MgO pripadaju najboljim materijalima u više područja primjene zbog velike gustoće, otpornosti na koroziju, mehaničke otpornosti i postojanosti obujma.

Osnovne djelatnosti u kojima se primjenjuju elektrolučno taljeni vatrostalni materijali na bazi MgO su: metalurgija, industrija stakla, cementa i vapna, elektrotermija, radiotehnika, procesna industrija, odnosno oblaganje opreme radi zaštite od abrazije, i proizvodnja abraziva.

$\mathrm{U}$ svijetu kvalitetni granulirani elektrolučno taljeni $\mathrm{MgO}$ proizvode samo ove tri tvrtke:

- Saint-Gobain Ceramic Materials, Francuska (do 1990. Norton, SAD) - Magnorite ${ }^{\circledR}$

- Rio Tinto Alcan, Kanada (do 2003. Sofrem Pechiney, Francuska)

- Dynamit Nobel, Njemačka.

One u posljednje vrijeme sve teže uspijevaju održati kvalitetu i postojanost isporuka svojih proizvoda.

Budući da se na području Republike Kosovo nalaze ležišta kvalitetnog magnezita, u ovome je radu istražena mogućnost proizvodnje vrlo čistog taljenog $\mathrm{MgO}$ iz magnezita iz ležišta Strezovce, Kosovo, za primjenu u elektrotermiji (vatrostalna masa za cijevne grijače).

Kako bi se očuvale elektroizolacijske i poboljšale mehaničke osobine pripravljenog granuliranog elektrolučno taljenog MgO, materijal je naknadno toplinski obrađen, pri čemu je praćena atmosfera u kojoj se MgO obrađuje, temperatura i trajanje obrade.

Ovako pripravljen MgO može se upotrijebiti u proizvodnji mase za izolatore cijevnih grijača i grijaćih ploča.

Proizvodnja MgO obuhvaća sljedeće operacije:

- dekarbonatizacija magnezita

- taljenje dobivenog dekarbonatiziranog magnezita (kaustični MgO)
- hlađenje i klasiranje

- mehanička obrada

- toplinska obrada (da se zadrže elektroizolacijske i poboljšaju mehaničke osobine $\mathrm{MgO}$ ).

Posebna pažnja mora se posvetiti izvođenju dekarbonatizacije, taljenju i naknadnoj toplinskoj obradi MgO.

\section{Eksperimentalni dio}

\section{Uzorkovanje}

Polazni materijal u istraživanju dobivanja magnezijeva oksida za proizvodnju elektrolučno taljenog MgO uzorak je "masivnog magnezita" iz ležišta Strezovce, Kosovo. Magnezit je kalciniran u rotacijskoj peći, produkt je sortiran te su izdvojene najbolje klase. Analizirani su uzorci u kojima je promjer zrna od 0 do $15 \mathrm{~mm}$. Pri odabiru magnezijeva oksida za daljnju obradu uzima se u obzir sljedeće:

- veličina zrna $(d=0-15 \mathrm{~mm})$

- kemijski sastav produkta, koji ovisi o zahtijevanim osobinama konačnog proizvoda

- stupanj kalcinacije materijala.

\section{Analiza uzoraka}

Rendgenska difrakcija provedena je difraktometrom Philips PW 10-51 s goniometrom PW 10-50, dok su analize TGA i DTA obavljene derivatografom C tvrtke MOM.

Kemijski sastavi uzoraka magnezita, pripravljenog kalciniranog MgO i elektrolučno taljenog MgO, određivani su gravimetrijski i volumetrijski standardnim analitičkim metodama u skladu s metodama ispitivanja vatrostalnih materijala $\mathrm{i}$ njihovim kemijskim analizama (JUS B. D8.225). ${ }^{7}$

Gustoća, obujamska masa i ukupna poroznost uzoraka određeni su živinim porozimetrom.

Kalcinirani magnezit taljen je u peći za elektrolučno taljenje u Kosovskoj Kamenici.

Taljeni MgO usitnjavan je čeljusnom drobilicom do promjera čestica $4 \mathrm{~mm}$, a do veličine čestica $0,4 \mathrm{~mm}$ udarnim mlinom s lopaticama pri brzini vrtnje 1450 okretaja u minuti. Do konačne veličine čestica od 0,03 do $0,04 \mathrm{~mm}$ $\mathrm{MgO}$ je usitnjen magnetskim separatorom tvrtke Exolon, SAD.

Sipkost MgO mjerena je lijevkom Ford promjera otvora 4,32 $\mathrm{mm}$ (istjecanje $100 \mathrm{~g}$ tvari ne smije trajati dulje od $32 \mathrm{~s})$.

Za taljenje je upotrijebljena trofazna nestacionarna peć Končar LP 3B 250.1600 snage 1600 kVA, koja radi u blok-postupku, s transformatorom 2TBVp 1600-121, snage 6000 kVA $(50 \mathrm{~Hz})$, obujma ulja $2000 \mathrm{l}$, s prinudnim vodenim hlađenjem. Na primarni namot narinut je napon 10 $k V$, a napon u sekundarnom namotu ovisi o trenutačnim postavkama transformatora (tablica 1).

Pod peći za elektrolučno taljenje MgO popločan je magnezijskim opekama debljine $300-400 \mathrm{~mm}$. Bočne oplate mogu se zamijeniti materijalom koji se obrađuje, a koji je smješten između bloka i plašta peći. Nastajanju električnog luka pomažu pomoćne elektrode postavljene između glavnih elektroda. Optimalni napon na početku taljenja 
T a b I i c a 1 - Izlazni naponi i struje transformatora peći

T a ble 1 - Secondary winding voltages and currents

\begin{tabular}{c|c|c|c|c|c|c|c|c|c|c|c}
\hline $\begin{array}{l}\text { Pozicija } \\
\text { Position }\end{array}$ & 1 & 2 & 3 & 4 & 5 & 6 & 7 & 8 & 9 & 10 & 11 \\
\hline U / V & 125 & 118,2 & 112 & 106,4 & 101,3 & 95,2 & 89,8 & 85 & 79,3 & 74,4 & 70 \\
I/A & 4,27 & 4,51 & 4,76 & 5,01 & 5,26 & 5,60 & 5,60 & 5,60 & 5,60 & 5,60 & 5,60 \\
\hline
\end{tabular}

je 110 - $140 \mathrm{~V}$, a tijekom rada napon se smanjuje i održava pri $80-90 \mathrm{~V}$.

Potrošnja električne energije po toni istaljenog $\mathrm{MgO}$ je 2000 - 3000 kWh.

Kotao peći sastoji se od dna i omotača, a postavljen je na kotačima te se može izvući ispod elektroda. Elektrode nisu u kotlu za vrijeme pripreme materijala za taljenje i tijekom hlađenja nakon taljenja, nego se upotrebljavaju u drugom kotlu. Nosači držača na gornjem dijelu elektroda pomiču se elektromehanički i mehanički jačim zavrtanjem blokiraju elektrode. Gornji slobodni dio iznad držača udaljen je najviše $1600 \mathrm{~mm}$. Elektrode su grafitne, promjera $300 \mathrm{~mm}$, duljine 3000 mm i s mogućnošću produljivanja do 6000 mm. Držači elektroda i čelični omotač peći hlade se vodom, a elektrode se podešavaju elektronički.

Kalcinirani magnezit (kaustični MgO) za jedan ciklus taljenja doprema se iz prostorije pored peći. Na dno kotla postavljene su pomoćne elektrode u obliku trokuta, pokri-

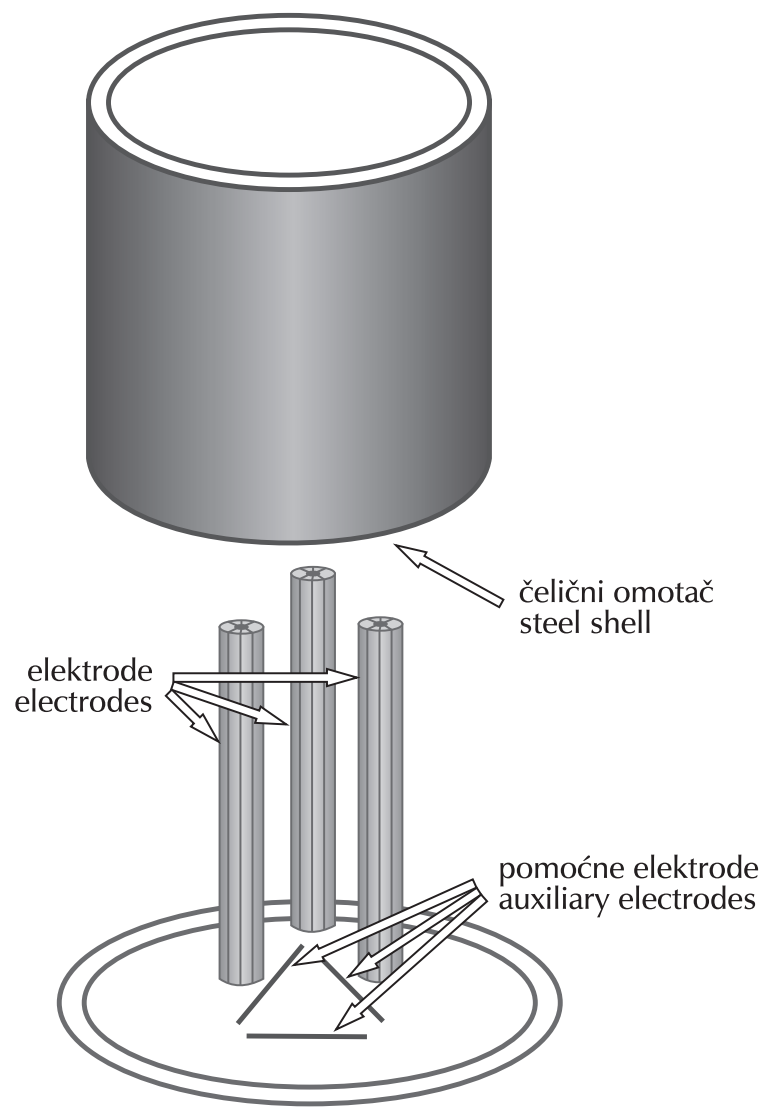

S I i k a 1 - Shema peći za elektrolučno taljenje $\mathrm{MgO}$

F i g. 1 - Schematic of electric arc furnace for MgO melting vene magnezijevim oksidom. Od spuštenih elektroda dvije dodiruju kutove trokuta a treća je podignuta za nekoliko centimetara (slika 1). Nakon uključivanja peći, tj. puštanja struje izazove se kratak spoj na elektrodama, razvije se visoka temperatura i počne taljenje.

Dok električni luk tali materijal, dodaje se još MgO (kaustični MgO). Kad nastane dovoljna količina taline, elektrode se oslobađaju i uključuje automatsko vođenje (pri dovoljno jakoj struji, više od 2000 A po elektrodi), a potom poveća napon da bi se povećala snaga peći. Neprestano se dodaje kaustičini MgO, tako da luk bude uvijek zatvoren, čime se omogućava miran rad peći i sprječavaju gubitci materijala koji se tali.

Elektroizolacijska svojstva granulirane mase magnezijeva oksida ispitivana su standardnim metodama za gotove proizvode elektrotermije (VDE 0470/1.51 par 20). ${ }^{2,11}$

Mehanička svojstva određivana su standardnom metodom po Vickersu uređajem Durimet Leitz Wetzlar prema normama (norme DIN 50133 i JUS C.A. 4204)..$^{5,8}$

\section{Rezultati i rasprava}

Za istraživanje je zbog visoke čistoće izabran masivni magnezit iz ležišta Strezovce, Kosovo (tablica 2).

Ta blic a 2 - Kemijski sastav rude magnezita

Ta ble 2 - Chemical analysis of magnesite ore

\begin{tabular}{c|c|c|c|c|c}
\hline $\begin{array}{c}\text { Gubitak } \\
\text { žarenjem } / \% \\
\text { Ignition loss } / \%\end{array}$ & $\begin{array}{c}w\left(\mathrm{SiO}_{2}\right) / \\
\%\end{array}$ & $\begin{array}{c}w\left(\mathrm{Fe}_{2} \mathrm{O}_{3}\right) / \\
\%\end{array}$ & $\begin{array}{c}w\left(\mathrm{Al}_{2} \mathrm{O}_{3}\right) / \\
\%\end{array}$ & $\begin{array}{c}w(\mathrm{CaO}) / \\
\%\end{array}$ & $\begin{array}{c}w(\mathrm{MgO}) / \\
\%\end{array}$ \\
\hline 51,46 & 0,54 & 0,09 & 0,08 & 0,87 & 46,96 \\
\hline
\end{tabular}

Rendgenski difraktogram (slika 2) pokazuje da se ruda magnezita sastoji od magnezita $\left(\mathrm{MgCO}_{3}\right)$ i nešto dolomita $\left(\mathrm{CaCO}_{3} \cdot \mathrm{MgCO}_{3}\right)$. Količina ostalih nečistoća je zanemariva i nisu se mogle registrirati.

Magnezitna ruda $\left(\mathrm{MgCO}_{3}\right)$ kalcinirana je u rotacijskoj peći duljine $85 \mathrm{~m}$, promjera 2,5 m, a u zoni sinteriranja promjer peći iznosi 3,0 m.

Rezultati diferencijalne termičke i termogravimetrijske analize prikazani su na slici 3.

Produkt kalciniranja (kaustični MgO), analiziran je nakon 12 sati kalciniranja, kada je rad peći ustaljen, s temperaturama $900-920{ }^{\circ} \mathrm{C}$. Nastali kaustični MgO kemijskim sastavom (tablica 3) ispunjava uvjete za daljnju obradu elektrolučnim taljenjem (tablica 4). 


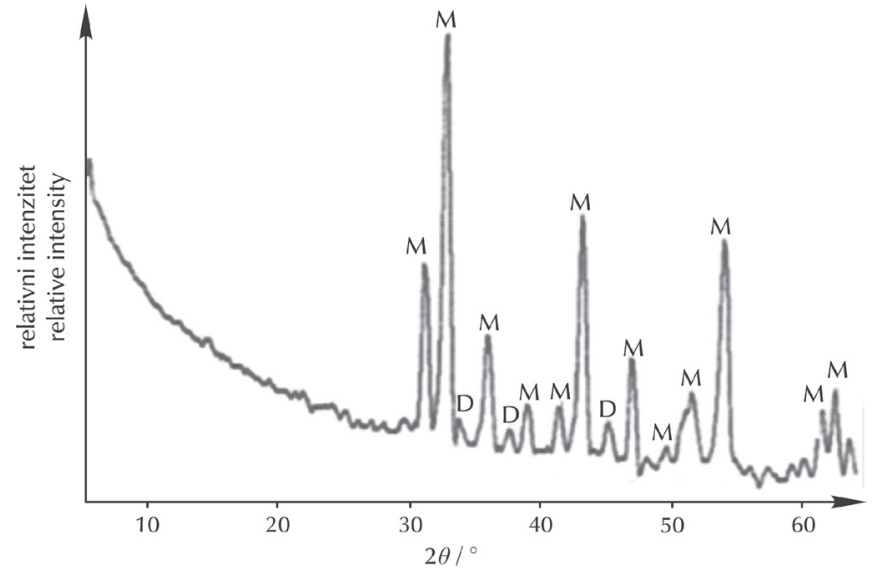

SIika 2 - Rendgenski difraktogram rude magnezita (M magnezit, $D$ - dolomit)

F i g. 2 - X-ray diffractogram of magnesite ore ( $M$ - magnesite, $D$ - dolomite)

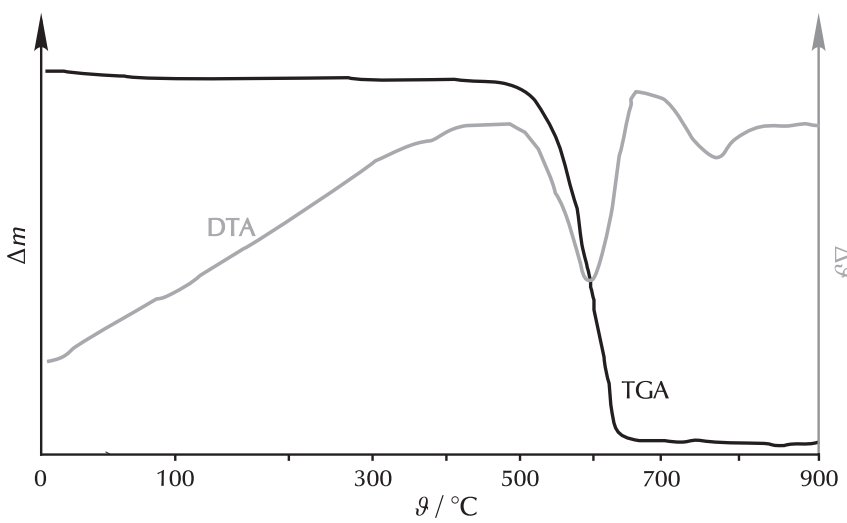

S l i k a 3 - DTA i TGA magnezitne rude

Fig. 3 - Results of DTA and TGA analysis of magnesite ore used

Ta bli c a 3 - Kemijski sastav kalciniranog magnezita

T a ble 3 - Chemical analysis of calcinated magnesite ore

\begin{tabular}{c|c|c|c|c|c}
\hline $\begin{array}{c}\text { Gubitak } \\
\text { žarenjem / } \% \\
\text { Ignition loss / } \%\end{array}$ & $\begin{array}{c}w\left(\mathrm{SiO}_{2}\right) / \\
\%\end{array}$ & $\begin{array}{c}w\left(\mathrm{Fe}_{2} \mathrm{O}_{3}\right) / \\
\%\end{array}$ & $\begin{array}{c}w\left(\mathrm{Al}_{2} \mathrm{O}_{3}\right) / \\
\%\end{array}$ & $\begin{array}{c}w(\mathrm{CaO}) / \\
\%\end{array}$ & $\begin{array}{c}w(\mathrm{MgO}) / \\
\%\end{array}$ \\
\hline 0,24 & 0,99 & 0,21 & 0,23 & 1,56 & 96,77
\end{tabular}

T a bli c a 4 - Zahtijevani kemijski sastav MgO za elektrolučno taljenje

$\mathrm{T}$ a ble 4 - Composition of $\mathrm{MgO}$ required for electric arc melting

\begin{tabular}{c|c|c|c|c|c}
\hline $\begin{array}{c}\text { Oznaka } \\
\text { uzorka } \\
\text { Sample code }\end{array}$ & $\begin{array}{c}w\left(\mathrm{SiO}_{2}\right) / \\
\%\end{array}$ & $\begin{array}{c}w\left(\mathrm{Fe}_{2} \mathrm{O}_{3}\right) \\
/ \%\end{array}$ & $\begin{array}{c}w\left(\mathrm{Al}_{2} \mathrm{O}_{3}\right) \\
/ \%\end{array}$ & $\begin{array}{c}w(\mathrm{CaO}) / \\
\%\end{array}$ & $\begin{array}{c}w(\mathrm{MgO}) / \\
\%\end{array}$ \\
\hline A & 0,97 & 1,02 & 0,48 & 2,16 & 95,37 \\
B & 1,48 & 0,89 & 0,64 & 2,07 & 94,92 \\
C & 0,75 & 0,68 & 0,53 & 1,87 & 96,17 \\
D & 0,81 & 0,74 & 0,61 & 1,58 & 96,26 \\
E & 0,95 & 0,72 & 0,86 & 1,94 & 95,53 \\
\hline
\end{tabular}

Prilikom taljenja u elektropeći moguća je redukcija MgO, koja je svakako neželjen proces, na koju se nastavlja izgaranje magnezija praćeno prskanjem taline oko elektroda. Teorijski se redukcija MgO zbiva iznad temperature 1800 ${ }^{\circ} \mathrm{C}$. Produkt ove redukcije iz peći izlazi kao bijeli dim i djelomično se taloži na elektrodama. Po završetku taljenja MgO isključuje se struja i elektrode izvlače iz peći.

Materijal ostaje dva do tri dana u kotlu radi hlađenja, a potom se rastaljeni MgO oslobađa od zasipa (nerastaljenog kaustika), koji je imao vatroizolacijsku ulogu između omotača kotla i taline.

Taljeni se $\mathrm{MgO}$, ohlađen do temperature $50-60{ }^{\circ} \mathrm{C}$, skida s kotla, razbija i ručno razvrstava.

Različita područja taljenog bloka razlikuju se po kemijskom sastavu, gustoći i strukturi. Ova je nehomogenost posljedica zonske građe, koja je određena stupnjem rastaljenosti materijala, uvjetima kristalizacije u pojedinim područjima, migracijom prisutnih oksida i drugim čimbenicima. Na površini bloka ostaje nedopek - bijela masa izgrađena od praha koji je po svom sastavu blizak kalciniranom (kaustičnog) magnezitu. Na slici 4 prikazana je građa taljenog bloka $\mathrm{MgO}$.

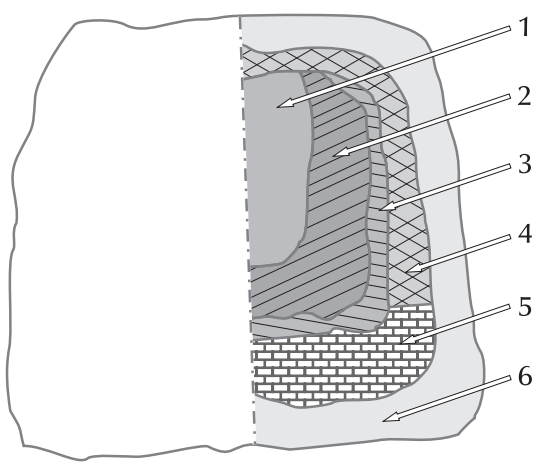

SIika 4 - Shema zonske građe elektrolučno taljenog bloka MgO: 1 - središnja zona, 2 - periferno područje, 3 - područje monokristala, 4 - bočna kora, 5 - donja kora, 6 - zasip (nedopek) F i g. 4 - Zonal structure of electric arc fused MgO block: 1 central zone, 2 - peripheral zone, 3 - monocrystal zone, 4 - lateral crust, 5 - lower crust, 6 - stowage

Kemijska analiza materijala u pojedinim zonama pokazuje da je najčistiji MgO u monokristalnoj i perifernoj zoni. Veličina kristala raste od središnjeg područja bloka, dostižući maksimalnu veličinu u zoni monokristala, a zatim se u kori naglo smanjuje.

U peći za elektrolučno taljenje obrađeno je 3600 kg kalciniranog MgO. Nakon taljenja dobiveni produkt je klasiran, a maseni udjeli pojedinih klasa su:

- 21,5 \% za primjenu u elektrotermiji

- $37,5 \%$ za primjenu u vatrostalnoj industriji (opeke, nabojne mase i sl.)

- 33,5 \% nerastaljenog materijala koji se vraća u proizvodnju

- 7,5 \% gubitaka u procesu taljenja MgO (isparavanje uslijed redukcijskih uvjeta i visokih temperatura).

Najkvalitetniji je materijal (za primjenu u elektrotermiji) nakon laboratorijske pripreme kemijski analiziran i rezul- 
tati su prikazani u tablici 5. Primjesa je vrlo malo, a udjel MgO iznosi 97,43 \%. Materijal je također fizički karakteriziran i rezultati su prikazani u tablici 6 .

Ta bli c a 5 - Kemijski sastav taljenog MgO

T a b le 5 - Chemical analysis of melted $\mathrm{MgO}$

\begin{tabular}{c|c|c|c|c|c}
\hline $\begin{array}{c}\text { Cubitak } \\
\text { žarenjem / } \% \\
\text { Ignition loss / } \\
\%\end{array}$ & $\begin{array}{c}w\left(\mathrm{SiO}_{2}\right) / \\
\%\end{array}$ & $\begin{array}{c}w\left(\mathrm{Fe}_{2} \mathrm{O}_{3}\right) \\
/ \%\end{array}$ & $\begin{array}{c}w\left(\mathrm{Al}_{2} \mathrm{O}_{3}\right) / \\
\%\end{array}$ & $\begin{array}{c}w(\mathrm{CaO}) / \\
\%\end{array}$ & $\begin{array}{c}w(\mathrm{MgO}) / \\
\%\end{array}$ \\
\hline 0,00 & 0,98 & 0,12 & 0,14 & 1,33 & 97,43
\end{tabular}

T a bli c a 6 - Fizičke osobine taljenog $\mathrm{MgO}$

T a b l e 6 - Physical properties of melted MgO

\begin{tabular}{c|c|c|c}
\hline$\varphi_{\mathrm{p}} / \%$ & $A_{\mathrm{w}} / \%$ & $\rho / \mathrm{g} \mathrm{cm}^{-3}$ & $\rho_{V} / \mathrm{g} \mathrm{cm}^{-3}$ \\
\hline $5,25-5,60$ & $1,5-2,1$ & 3,90 & 3,65 \\
\hline
\end{tabular}

Čistoća MgO dobivenog procesom taljenja u elektrolučnoj peći potvrđena je rendgenskom difrakcijskom analizom i rezultati su prikazani na slici 5. Na difraktogramu je vidljivo da nema neželjenih primjesa.

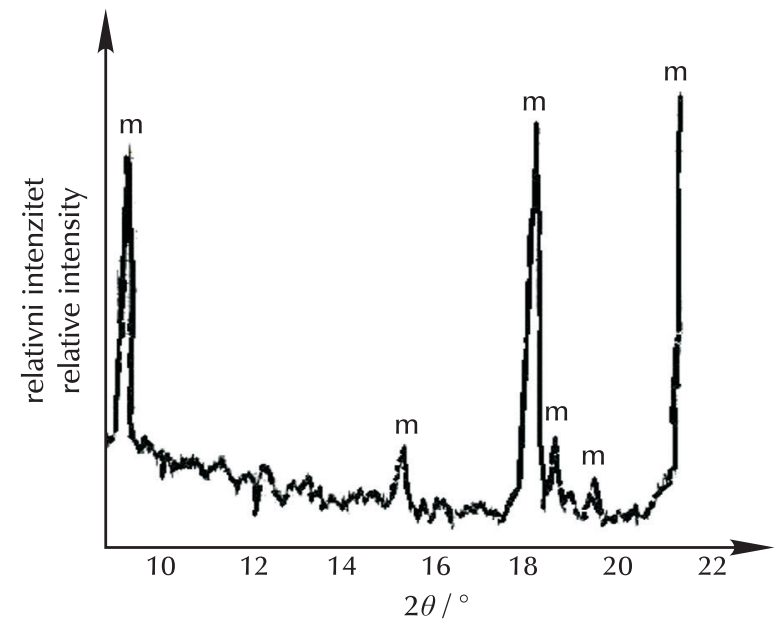

S I i k a 5 - Rendgenski difraktogram elektrolučno taljenog $\mathrm{MgO}$ ( $m$ - taljeni $\mathrm{MgO}$ )

F i g. 5 - X-ray difractogram of the melted $\mathrm{MgO}(\mathrm{m}$ - melted $\mathrm{MgO})$

U procesu proizvodnje elektrolučno taljenog $\mathrm{MgO}$ reakcijom MgO s oksidima drugih elemenata nastaju određene mineralne faze. Tijekom hlađenja i prerade stvaraju se strukturne pogreške u kristalnoj rešetki, koje se očituju kao pukotine i zaostale napetosti u zrnima, a koje doprinose nekontroliranom pucanju zrna MgO. Ove pojave pogoršavaju elektroizolacijske i mehaničke osobine. Stoga se $\mathrm{MgO}$ naknadno toplinski obrađuje.

Pripremljeni granulirani MgO za elektrotermiju posebnim se postupkom prerađuje do elektroizolacijskih masa za cijevne grijače i grijaće ploče. Tražena svojstva kvalitetnih masa za cijevne grijače su: visoka kemijska čistoća, dobra toplinska vodljivost, veliki omski otpor, otpornost prema hidrataciji, velika gustoća u zbijenu stanju, visoka temperatura sinteriranja, visoko talište, sipkost, dobra mehanička svojstva. Ove uvjete potpuno ispunjava elektrolučno taljeni MgO pa je izabran kao temeljni materijal za izolacijske mase cijevnih grijača i grijaćih ploča. Izolacijska masa od magnezijeva oksida proizvodi se drobljenjem, mljevenjem, magnetskim separiranjem, razvrstavanjem, homogeniziranjem i žarenjem na povišenim temperaturama.

Uzorak elektrolučno taljenog MgO koji je dalje istraživan nosi oznaku S-tip M-11 (S - Strezovce, M - masa). Kemijski sastav prikazan je u tablici 7, a granulometrijski sastav u tablici 8 .

T a b I i c a 7 - Kemijski sastav uzorka elektrotaljenog MgO S-tip M-11

T a b l e 7 - Chemical analysis of examined mass S-type M-11

\begin{tabular}{c|c|c|c|c|c}
\hline $\begin{array}{c}w\left(\mathrm{SiO}_{2}\right) / \\
\%\end{array}$ & $\begin{array}{c}w\left(\mathrm{Fe}_{2} \mathrm{O}_{3}\right) \\
/ \%\end{array}$ & $\begin{array}{c}w\left(\mathrm{Al}_{2} \mathrm{O}_{3}\right) \\
/ \%\end{array}$ & $\begin{array}{c}w(\mathrm{CaO}) / \\
\%\end{array}$ & $\begin{array}{c}w(\mathrm{MgO}) / \\
\%\end{array}$ & $\begin{array}{c}w\left(\mathrm{SiO}_{2}\right) / \\
w(\mathrm{CaO})\end{array}$ \\
\hline 0,84 & 0,07 & 0,06 & 0,96 & 98,07 & 0,875 \\
\hline
\end{tabular}

Tablica 8 - Granulometrijska analiza istraživanog uzorka elektrotaljenog MgO S-tip M-11

T a b I e 8 - Size analysis of examined mass S-type M-11

\begin{tabular}{lrrrrrr}
\hline $\begin{array}{l}\text { otvor sita } / \mathrm{mm} \\
\text { sieve size } / \mathrm{mm}\end{array}$ & $-0,4$ & 0,25 & 0,15 & 0,1 & 0,09 & 0,06 \\
\hline$w($ frakcija) $/ \%$ & 24,0 & 28,0 & 24,0 & 8,0 & 10,0 & 6,0 \\
$w($ fraction $) / \%$ & & & $-0,1$ & $-0,09$ & $-0,06$ & $-0,03$ \\
\hline
\end{tabular}

Uzorak S-tip M-11 uspoređen je kemijski (tablica 9) i granulometrijski (tablica 10) uspoređen s uzorcima najpoznatijih izolacijskih masa dostupnih na tržištu.

Tablica 9 pokazuje da je u uzorcima komercijalno dostupnih izolacijskih masa prisutan borov(III) oksid $\left(\mathrm{B}_{2} \mathrm{O}_{3}\right)$, koji negativno utječe na kakvoću vatrostalnog materijala proizvedenog na osnovi taljenog MgO dobivenog iz morske vode. Naime, mehanička otpornost vatrostalnog $\mathrm{MgO}$ na visokim temperaturama znatno opada s porastom sadržaja $\mathrm{B}_{2} \mathrm{O}_{3}$, a smanjuje se i modul elastičnosti takvih vatrostalnih materijala.

Štoviše, i najkvalitetniji elektrotaljeni MgO sadrži određene količine primjesa oksida raznih elemenata bez obzira na kvalitetu i prirodu polazne sirovine, pa je za njegovu uspješnu primjenu potrebno znati utjecaj svake prisutne primjese na mehaničke i elektroizolacijske osobine.

Od prisutnih oksida najizrazitije pozitivno djelovanje ima $\mathrm{Al}_{2} \mathrm{O}_{3}$, a potom $\mathrm{MnO}, \mathrm{TiO}_{2}$ i $\mathrm{NiO}_{2}$, čija je količina neznatna pa su zanemarivi. Prisutnost $\mathrm{Al}_{2} \mathrm{O}_{3}$ povećava otpornost na tlak (mikrotvrdoća), što je u primjeni ovih materijala od izrazite važnosti. Međutim, uz veće količine ostalih primjesa $\mathrm{Al}_{2} \mathrm{O}_{3}$ snižava temperaturu sinteriranja $\mathrm{MgO}$. $\mathrm{CaO}$ štetno djeluje zbog velike sklonosti hidrataciji, što pogoršava elektroizolacijske osobine elektrotaljenog MgO. Težnja hidrataciji $\mathrm{CaO}$, a i $\mathrm{MgO}$, smanjuje se uz $\mathrm{SiO}_{2}$.

Da bi se u procesu proizvodnje zadržala elektroizolacijska svojstva i zadovoljavajuća otpornost na tlak MgO, posebna pažnja mora se posvetiti taljenju, mehaničkoj preradi i termičkoj obradi. 
T a b li c a 9 - Kemijski sastav trgovačkih izolacijskih masa

T a ble 9 - Chemical analysis of commercial insulating masses

\begin{tabular}{l|c|c|c|c|c|c|c}
\hline $\begin{array}{c}\text { Uzorak } \\
\text { Sample }\end{array}$ & $w\left(\mathrm{SiO}_{2}\right) / \%$ & $w\left(\mathrm{Fe}_{2} \mathrm{O}_{3}\right) / \%$ & $w\left(\mathrm{Al}_{2} \mathrm{O}_{3}\right) / \%$ & $w(\mathrm{CaO}) / \%$ & $w(\mathrm{MgO}) / \%$ & $w\left(\mathrm{~B}_{2} \mathrm{O}_{3}\right) / \%$ & $\begin{array}{c}\left.w(\mathrm{SiO})_{2}\right) / \\
w(\mathrm{CaO})\end{array}$ \\
\hline Magnorite M-70 & 2,5 & 0,08 & 0,13 & 1,2 & 96,09 & 0,01 & 2,08 \\
Sofrem CA238 & 2,5 & 0,10 & 0,05 & 1,5 & 97,00 & 0,01 & 1,66 \\
Dyn. Nob. 1246CS & 1,1 & 0,04 & 0,04 & 1,2 & 97,60 & 0,01 \\
\hline
\end{tabular}

T a b I i c a 10 - Granulometrijska analiza trgovačkih izolacijskih masa

T a ble 10 - Size analysis of commercial insulating masses

\begin{tabular}{|c|c|c|c|c|c|c|}
\hline \multirow{3}{*}{$\begin{array}{l}\text { Uzorak } \\
\text { Sample }\end{array}$} & \multicolumn{6}{|c|}{$\begin{array}{l}\text { Otvor sita / mm } \\
\text { Sieve size /mm }\end{array}$} \\
\hline & $0,4-0,25$ & $0,25-0,15$ & $0,15-0,1$ & $0,1-0,09$ & $0,09-0,06$ & $0,06-0,03$ \\
\hline & \multicolumn{6}{|c|}{$\begin{array}{l}w(\text { frakcija }) / \% \\
w(\text { fraction }) / \%\end{array}$} \\
\hline Magnorite M-70 & 29,1 & 23,0 & 20,0 & 18,4 & 6,5 & 3,0 \\
\hline Sofrem CA238 & 18,0 & 35,0 & 21,0 & 14,0 & 10,0 & 2,0 \\
\hline Dyn. Nob. 1246CS & 25,0 & 27,0 & 27,0 & 4,0 & 11,0 & 6,0 \\
\hline
\end{tabular}

Za utvrđivanja optimalnih uvjeta termičke obrade usporedno su određivana elektroizolacijska svojstva pripravljene mase i izolacijskih masa najpoznatijih svjetskih tvrtki, standardnim metodama VDE 0470/1.51 par 20. Mehanička svojstva utvrđivana su standardnom metodom po Vickersu. Metoda se uobičajeno primjenjuje za određivanje mikrotvrdoće metala, ali se uz povećan broj mjerenja (više od pet) na svakom uzorku primjenjuje i kod nemetala.

Na povišenim su temperaturama mehanička svojstva ocijenjena putem vrijednosti mikrotvrdoće, koja je također odraz unutarnjih transformacija u kristalnoj strukturi MgO.

Toplinska obrada elektrotaljenog $\mathrm{MgO}$ provodi se radi poboljšanja mehaničkih i elektroizolacijskih svojstva. Prema nekim autorima naknadnom toplinskom obradom postiže se 40 \% veća otpornost na tlak, a i 50 \% bolja elektroizolacijska svojstva. ${ }^{10,11}$ Ovim se postupcima uklanjaju pogreške u kristalnoj strukturi MgO i uklanjaju se sumpor i ugljik zaostali nakon taljenja. Pri toplinskoj obradi kontrolirani su sljedeći uvjeti:

- atmosfera u kojoj se materijal obrađuje

- temperaturni raspon

- trajanje obrade.

Sastav atmosfere u kojoj je materijal podvrgnut toplinskoj obradi određen je parcijalnim tlakom kisika. Optimalan sastav ovisi o materijalu koji je podvrgnut obradi, u ovom slučaju elektrotaljeni MgO, a ovisi i o mineralnim fazama koje su prisutne uz MgO. Ostvarivanjem željenog mineralnog sastava izravno se utječe na mehanička i elektroizolacijska svojstva. ${ }^{11,12}$

Temperatura na kojoj se toplinski obrađuje materijal ovisi o mineralnom sastavu polazne tvari. Pri mehaničkoj obradi elektrotaljenog $\mathrm{MgO}$ povećava se aktivnost materijala (stvaranje novih defekata u kristalnoj strukturi i povećanje specifične površine) tako da se snižava temperatura na kojima počinje sinteriranje zrna MgO, pogotovo ako su pri- sutne nečistoće $\left(\mathrm{CaO}, \mathrm{Al}_{2} \mathrm{O}_{3}, \mathrm{SiO}_{2}, \mathrm{Fe}_{2} \mathrm{O}_{3}\right)$. U takvim uvjetima može doći do stvaranja kalcijeva aluminata $(\mathrm{CaO}$. $\mathrm{Al}_{2} \mathrm{O}_{3}$ ) i kalcijeva alumoferita u stabilnijem obliku tetrakalcijeva alumoferita $\left(4 \mathrm{CaO} \cdot(\mathrm{Al}, \mathrm{Fe})_{2} \mathrm{O}_{3}\right)$, koji se počinju taliti na temperaturama blizu $1300{ }^{\circ} \mathrm{C} .{ }^{12}$

Za postizanje željenog mineralnog sastava potrebno je obradu provoditi na temperaturama do $1200{ }^{\circ} \mathrm{C}$, a za uklanjanje defekata u kristalnoj strukturi, tj. smanjenje aktivnosti $\mathrm{MgO}$, nužno je postići temperature do $1300{ }^{\circ} \mathrm{C}$. Nakon postizanja ovih temperatura materijal se naglo hladi.

Ukupno trajanje toplinske obrade određeno je stanjem kristalne strukture MgO i količinom prisutnih primjesa i varijabla je koju se mora neovisno utvrditi za svaki novi materijal.

Toplinskom se obradom što više željeza u MgO treba izdvojiti u obliku ferita $\left(\mathrm{MgO} \cdot \mathrm{Fe}_{2} \mathrm{O}_{3}\right)$ na granici zrna, jer se time razaraju kompleksi kation / anionska praznina i anion / kationska praznina.

U radu je određena najviša temperatura na kojoj se uklanjaju defekti u kristalnoj strukturi $\mathrm{MgO}$, a nakon toga materijal je naglo ohlađen da bi se zadržalo postignuto stanje. ${ }^{13,14} \mathrm{U}$ istraživanjima je mijenjano vrijeme podizanja temperature i vrijeme održavanja najviše temperature. Gornja dopuštena temperaturna granica određena je sklonošću zrna sinteriranju. Iznad $1200{ }^{\circ} \mathrm{C}$ zrna elektrotaljenog $\mathrm{MgO}$ počinju djelomično sinterirati, a sipkost materijala prelazi dopuštenu vremensku granicu od 32 s na 100 g materijala.

Provedena su dva ispitivanja toplinske obrade s dvama različitim vremenima zadržavanja na najvišoj temperaturi (60 i 120 min). Najviša temperatura mijenjana je za $50{ }^{\circ} \mathrm{C}$ u rasponu od 950 do $1200{ }^{\circ} \mathrm{C}$. Toplinska obrada trajala je od 120 do 240 min, kao što je prikazano u tablici 11. Ukupno je analizirano 12 uzoraka, koji su uspoređeni s uzorcima (br. 13, 14 i 15) komercijalnih materijala. 
T a b I i c a 11 - Parametri toplinske obrade MgO

$\mathrm{T}$ a ble 11 - Parameters of heat treatment of $\mathrm{MgO}$

\begin{tabular}{c|c|c|c|c|c}
\hline $\begin{array}{c}\text { Broj ciklusa } \\
\text { Cycle number }\end{array}$ & $\begin{array}{c}\text { Br. } \\
\text { No. }\end{array}$ & $\vartheta_{0} /{ }^{\circ} \mathrm{C}$ & $\begin{array}{c}\vartheta_{\max } / \\
{ }^{\circ} \mathrm{C}\end{array}$ & $\begin{array}{c}t_{\max } / \\
\min \end{array}$ & $t / \min$ \\
\hline 1 & 1 & 650 & 950 & 60 & 130 \\
& 2 & 650 & 1000 & 60 & 140 \\
& 3 & 650 & 1050 & 60 & 150 \\
& 5 & 650 & 1100 & 60 & 160 \\
& 6 & 650 & 1150 & 60 & 170 \\
& 7 & 650 & 950 & 120 & 190 \\
& 8 & 650 & 1000 & 120 & 200 \\
& 9 & 650 & 1050 & 120 & 210 \\
& 10 & 650 & 1100 & 120 & 220 \\
& 11 & 650 & 1150 & 120 & 230 \\
& 12 & 650 & 1200 & 120 & 240 \\
\hline Magnorite M-70 & 13 & - & - & - & - \\
Sofrem CA238 & 14 & - & - & - & - \\
Dyn. Nob. 1246CS & 15 & - & - & - & - \\
\hline
\end{tabular}

Elektroizolacijska svojstva svih uzoraka mjerena su pod istim uvjetima, a prije mjerenja određeni su kemijski sastav, granulometrijski sastav, nasipna gustoća i sipkost.

Rezultati su pokazali da nije došlo do bitnih promjena ni u jednoj karakteristici u odnosu na polazne.

Mikrotvrdoća je mjerena na zrnima elektrolučno taljenog $\mathrm{MgO}$ veličine čestica do $0,4 \mathrm{~mm}$. Zrna su učvršćena pastom oblika valjka promjera $0,5 \mathrm{~cm}$ i visine $1,5 \mathrm{~cm}$, nakon čega su polirane obje baze valjka za mikroskopska ispitivanja u odbijenoj svjetlosti. Za određivanje mikrotvrdoće upotrijebljen je uređaj Durimet Leitz Wetzlar prema normama DIN 50133 i JUS C.A. 4204. Mikrotvrdoća je određena tako da je pod mikroskopom pronađeno mjesto pritiska te utisnut otisak pod željenim opterećenjem, uz konstantno vrijeme $15 \mathrm{~s}$, mikrotvrdoća se očita iz tablica prema promjeru otiska. Svaki od 12 uzoraka analiziran je deset puta, a uvijek se utiskuje u istu odgovarajuću plohu kristala MgO. Kako je došlo do rasipanja rezultata, što je uobičajeno s ovakvim materijalima, ekstremne vrijednosti su odbačene, a iz preostalih izračunata je srednja vrijednost kao što je prikazano u tablici 12.

Elektroizolacijske osobine elektrotaljenog $\mathrm{MgO}$ opadaju osobito ako su u njemu prisutni metali u elementarnom obliku (Fe), neki metali u obliku oksida ( $\left.\mathrm{FeO}, \mathrm{TiO}_{2}, \mathrm{MnO}\right)$, a također $\mathrm{i}$ ugljik i sumpor kao najprisutnije nemetalne primjese.

Pažljivom preradom do mase za cijevne grijače, izbjegavanjem kontaminacije metalnim primjesama kao i naknadnim žarenjem, pri čemu se ujedno oksidiraju ugljik, sumpor i željezo, mogu se očuvati elektroizolacijske i popraviti mehaničke osobine $\mathrm{MgO}$.

Za mehanička svojstva važno je da površina zrna MgO bude glatka, što se postiže odvajanjem kristala periklasa po određenim ravninama kalanja posebnim načinom usitnja-
T a b I i c a 12 - Mikrotvrdoća toplinski obrađenog MgO

$\mathrm{T}$ a ble 12 - Heat treated MgO microhardness

\begin{tabular}{c|c|c}
\hline Broj ciklusa & Br. & H $/ \mathrm{kg} \mathrm{mm}^{-2}$ \\
Cycle number & No. & 386 \\
& 2 & 442 \\
& 3 & 420 \\
& 4 & 394 \\
& 5 & 403 \\
& 6 & 438 \\
\hline & 7 & 376 \\
& 8 & 412 \\
& 9 & 422 \\
& 10 & 398 \\
& 11 & 413 \\
& 12 & 418 \\
\hline Magnorite M-70 & 13 & 448 \\
Sofrem CA238 & 14 & 464 \\
Dyn. Nob. 1246CS & 15 & 396 \\
neobrađeni MgO & 16 & 388 \\
untreated MgO & & \\
\hline
\end{tabular}

vanja, tako da zrna zadrže oblik kristala MgO. Time se povećava gustoća nakon zbijanja i čuvaju elektroizolacijska svojstva. Gustoća se može povećati i jednolikijom granulacijom materijala.

Zadovoljavajuću kvalitetu elektrotaljenog $\mathrm{MgO}$ u svijetu sada postiže samo nekoliko tvrtki. Istraživanje je pokazalo da se elektrolučno taljeni $\mathrm{MgO}$ dovoljno kvalitetan da se može primijeniti u elektrotermiji, može se proizvesti obradom kalciniranog magnezita iz ležišta Strezovce i kvalitetom je usporediv s MgO dostupnim na svjetskom tržištu.

\section{Zaključci}

Iz provedenih ispitivanja i prikazanih rezultata može se zaključiti sljedeće:

1. Analizom kemijskog sastava dobivenog kalciniranog MgO (tablica 3) uočava se veći udjel MgO, a manji udjel primjesa u odnosu na zahtjeve za kvalitetom (tablica 4).

2. Kemijska analiza elektrotaljenog $\mathrm{MgO}$ (tablica 5) pokazuje nizak sadržaj primjesa poput $\mathrm{SiO}_{2}, \mathrm{Fe}_{2} \mathrm{O}_{3}, \mathrm{Al}_{2} \mathrm{O}_{3} \mathrm{i}$ $\mathrm{CaO}$, a visok udio $\mathrm{MgO}(w=97,43 \%)$.

3. Tehničkim doradama elektropeći (kotao koji lagano rotira) može se poboljšati miješanje materijala i ujednačavanje njegova sastava, a time i dobiti kvalitetniji taljeni $\mathrm{MgO}$.

4. Postignut je visok sadržaj $\mathrm{MgO}(w=98,08 \%)$ u pripravi mase S-tip M-11 te je povoljniji u odnosu na komercijalno dostupne elektroizolacijske mase.

5. Za uporabu u pripravi elektroizolacijske mase važan uvjet predstavljaju oblik i raspored zrna elektrotaljenog $\mathrm{MgO}$. 
6. Mehanička i elektroizolacijska svojstva ovise o promjenama u strukturi kristala MgO.

7. Rezultati granulometrije, nasipne gustoće i mjerenja sipkosti pokazali su da nije došlo do bitnih promjena u odnosu na polazne vrijednosti nakon termičke obrade uzoraka masa za cijevne grijače.

8. Kemijska analiza uzoraka komercijalno dostupnih materijala (tablica 9) pokazuje prisutnost borova(III) oksida $\left(\mathrm{B}_{2} \mathrm{O}_{3}\right)$, koji negativno utječe na kakvoću vatrostalnog materijala proizvedenog na osnovi taljenog MgO.

9. Za dobivanje optimalnih mehaničkih i elektroizolacijskih svojstva kod elektrotaljenog MgO treba utvrditi uvjete toplinske obrade.

Na temelju koncipiranih i izvedenih istraživanja proizašli su rezultati iz kojih se može zaključiti da je uz optimalne uvjete u svim fazama postupka moguća priprava taljenog $\mathrm{MgO}$ iz kalciniranog magnezita ležišta Strezovce, Kosovo, za primjenu u elektrotermiji.

\section{Popis kratica i simbola}

\section{List of abbreviations and symbols}

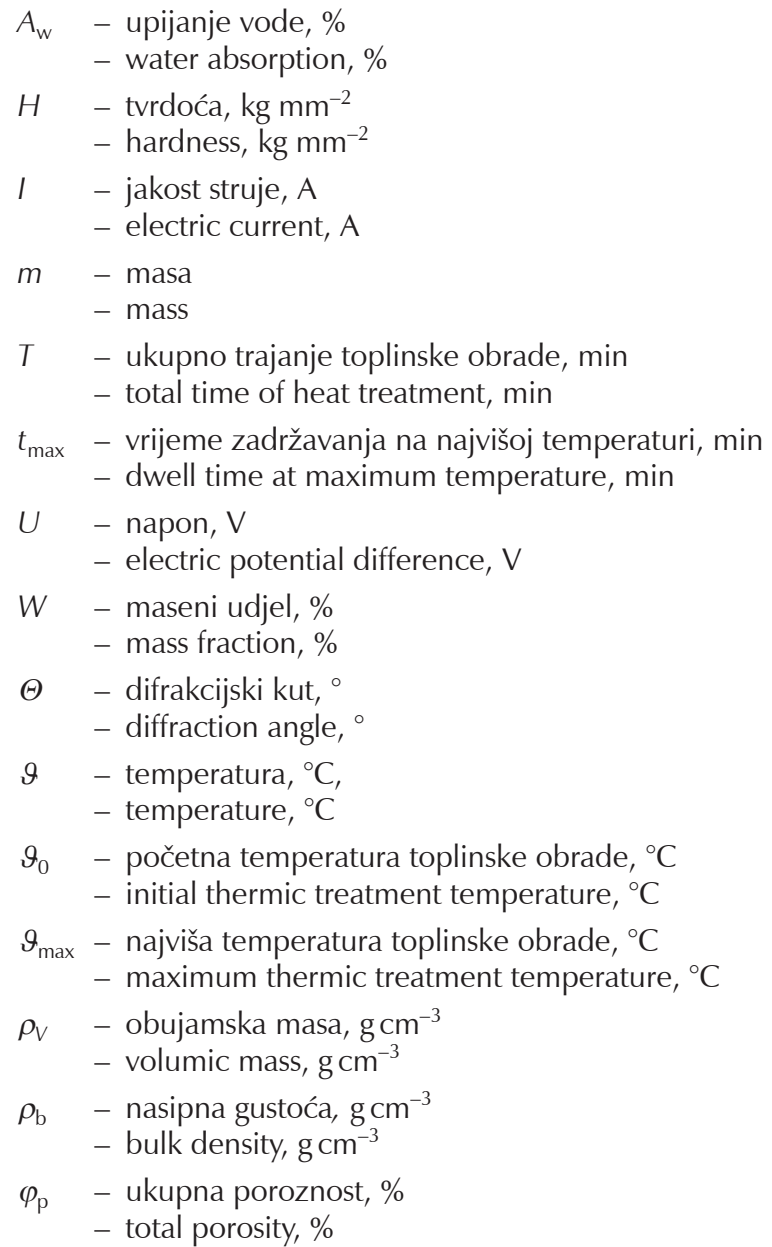

DTA - diferencijalna termička analiza

- differential thermal analysis

TGA - termogravimetrijska analiza

- thermogravimetric analysis

\section{Literatura \\ References}

1. P. P. Budnikov, D. N. Polubojarinov, Himičeskaja tehnologija keramiki i ogneuporov, Moskva, 1972., str. 123-241.

2. I. S. Kajnarskij, Processi tehnologii ogneuporov, Moskva, 1969., str. 143-257.

3. R. L. Duncan, Synthetic and Natural Magnesias, Ind. Minerals 7 (1986) 43-48.

4. M. Vučetić, Ž. Carićević, Investicioni program rekonstrukcije postrojenja elektrotopljenog $\mathrm{MgOCr}_{2} \mathrm{O}_{3}$ u Kosovskoj Kamenici, Sektor za investicije "Magnohrom", Kraljevo, 1982., str. 5-24.

5. M. Vučetić, Utvrđivanje optimalnih uslova termičke obrade granuliranog elektrotopljenog $\mathrm{MgO}$, magistarski rad, Tehnološki fakultet, Zagreb, 1976., str. 103.

6. M. Vučetić, V. Simonović, Industrijska prerada elektrotopljenog MgO do mase za cevne grejače, Magnohrom, Kraljevo, 1976., str. 23-28.

7. Metode ispitivanja vatrostalnih materijala - Hemiska ispitivanja magnezita i magnezitnih proizvoda, JUS B. D8.225, postupak utemeljen na normama $\mathrm{H}-2$ do $\mathrm{H}-17$, Biblioteka tehničkih knjiga, Magnohrom, Kraljevo, 1984., str. 60-75.

8. S. P. Mitoff, Electronic and Ionic Conductivity in Single Crystals of MgO, J. Chem. Phys. 36 (1962) 1383-1389.

9. S. Hoda, Sh. Rashani, M. Shaqiri, M. Sadiku, A. Azizi, Kinetika izluživanja kalcija iz dolomita, Kem. Ind. 60 (6) (2011) 335342.

10. E. Ryshkewitch, Oxide Ceramics, Academic Press, London, 1960., str. 234-262.

11. J. D. Tretjakov, Termodinamika ferritov, Izdat. Khim., Lenjingrad, 1967., str. 115-172.

12. A. S. Berežnoj, Mnogokomponentnie sistemi okislov, Naukova Dumka, Kijev, 1970., str. 145-176.

13. R. Kneschke, R. Sahxade, Berichte der DKG 46 (1969) 12-21.

14. A. F. Bessonov, V. M. Ustajancev, Ogneupori 8 (1965) 30-34

15. T. Murata, F. S. Howell, K. Itatani, Sinterability of Magnesium-oxide Powder containing Spherical Agglomerates, J. Mater. Sci. 36 (2001) 1277-1284.

16. N. Petric, B. Petric, E. Tkalčec, V. Martinac, N. Bogdanić, M. Mirošević-Anzulović, Effect of Additives on Sintering of Magnesium Oxide obtained from Sea Water, Sci. Sinter. 19 (1987) 81-87.

17. L. Rada, Der Einflub von Mineralisatoren auf das Sintern von Magnesiumoxid, Keram. Z. 48 (1996) 808-811.

18. T. S. Liu, R. J. Stokes, C. H. Li, Fabrication and Plastic Behavior of Single-Crysta $\mathrm{MgO}-\mathrm{NiO}$ and $\mathrm{MgO}-\mathrm{MnO}$ Solid-Solution Alloys, J. Am. Ceram. Soc. 47 (1964) 276-279.

19. E. Mustafa, N. Khalil, A. Gamal, Sintering and Microstructure of Spinel-Forsterite Bodies, Ceram. Int. 28 (2002) 663-667. 


\section{SUMMARY}

\section{Preparation of Electrically Fused Magnesium Oxide from Calcined Magnesite for Use in Electrothermics}

S. Hoda, ${ }^{*}$ I. Zeqiri, M. Sadiku, M. Kelmendi, and B. Baruti

Nowadays, there is a great need for materials that can withstand oxidative environment at very high temperatures. The most important material for such use is electrically fused $\mathrm{MgO}$ with melting point $3098 \mathrm{~K}$ and of great importance in the production of high-heat-resistant materials. $\mathrm{MgO}$ crystals obtained from melt have a regular structure, with few structural faults, compared to $\mathrm{MgO}$ crystals, which are formed at lower temperatures by sintering process.

The goal of this work is the preparation of pure electrically fused $\mathrm{MgO}$ for use in electrothermics, from calcinated magnesite. Because the Republic of Kosovo possesses grade magnesite $\left(\mathrm{MgCO}_{3}\right)$, in this research for preparation of pure fused $\mathrm{MgO}$ in the electromelting furnace in Kosovska Kamenica samples of Strezovce magnesite deposit were used. After granulated fused MgO preparation, the optimum heat treatment and hardness were determined under controlled atmosphere, temperature range, and total time.

Based on the research presented in this paper, it can be concluded that under optimal conditions at all stages, from calcined magnesite deposits of Strezovce, Republic of Kosovo, possible is the preparation of fused $\mathrm{MgO}$ for use in electrothermics, of quality comparable to $\mathrm{MgO}$, which is available on the world market.

Fakulteti i Gjeoshkencave dhe Teknologjisë, PIM Trepça, 40000 Mitrovicë, Kosovo 